\title{
Density, biomass and productivity of animals in four subtidal rocky reef habitats: the importance of small mobile invertebrates
}

\author{
Richard B. Taylor* \\ Leigh Marine Laboratory and School of Biological Sciences, University of Auckland, PO Box 349, Warkworth, New Zealand
}

\begin{abstract}
Density, biomass and productivity of animals $>0.5 \mathrm{~mm}$ were estimated in 4 shallow subtidal rocky reef habitats in temperate northeastern New Zealand. The main objective was to determine the relative contributions of mobile epifauna $(0.5-10 \mathrm{~mm})$ and megafauna $(>10 \mathrm{~mm})$ to the flux of materials on the reef. The habitats surveyed were (1) Carpophyllum plumosum var. capillifolium forest (Phaeophyceae: Fucales), (2) Ecklonia radiata forest (Phaeophyceae: Laminariales), (3) urchin barrens, and (4) articulated coralline algal turf flats. Epifauna comprised $>99.5 \%$ of individuals in each habitat. Epifauna dominated biomass $(>86 \%)$ in the finely structured Carpophyllum forest and turf flats, where they contributed $>97 \%$ of total secondary productivity. Although lower in the other 2 habitats, the epifaunal contribution to total secondary productivity was still $\sim 78 \%$ on the scale of the entire reef. These results show that epifauna are major contrihutors to the flux of materials in rocky reef habitats, and should therefore be included in trophic models of these systems. Consumption by fish could only account for $-26 \%$ of epifaunal production, with the fate of the remainder unknown. Estimated annual secondary productivity within the Carpophyllum torest and turf flats habitats (100 to $115 \mathrm{~g} \mathrm{AFDW} \mathrm{m}^{-2}$ $\mathrm{yr}^{-1}$ ) was higher than literature values for a range of soft sediment habitats, and was exceeded only by 2 other hard-bottom communities.
\end{abstract}

KEY WORDS: Biomass - Epifauna - Kelp forest - New Zealand Rocky reef $\cdot$ Seaweed - Secondary productivity

\section{INTRODUCTION}

Temperate rocky reefs are inhabited by large numbers of small crustaceans, gastropods and polychaetes, but the extent to which these epifaunal organisms contribute to the flux of materials on rocky reefs is unclear. Previous quantitative studies (Miller et al. 1971, Newell et al. 1982) have focussed on larger animals such as echinoids, lobsters and fish (hereafter 'megafauna'; $>10 \mathrm{~mm}$ long), and microorganisms (bacteria). However, epifauna (0.5 to $10 \mathrm{~mm}$ long) are also likely to be important consumers, producers and nutrient recyclers. They are extremely abundant on many ben-

\footnotetext{
- Present address: Institute of Marine Sciences, University of North Carolina at Chapel Hill, 3431 Arendell St., Morehead City, North Carolina 28557, USA.

E-mail: rbtaylor@mail.clis.com
}

thic substrata (e.g. Choat \& Kingett 1982, Holbrook \& Schmitt 1989, Taylor \& Cole 1994), have high metabolic rates (Edgar \& Moore 1986), and are productive enough to support large populations of small predatory fishes (e.g. Simenstad et al. 1977, Moreno \& Jara 1984, Edgar \& Moore 1986, Jones 1988, Holbrook et al. 1990).

Energy flow studies at the ecosystem level on rocky reefs have been carried out at St Margaret's Bay in Nova Scotia (Miller et al. 1971), and at the Cape Peninsula in South Africa (Field et al. 1977, Velimirov et al. 1977, Newell et al. 1982, review of Branch \& Griffiths 1988). The flux measured in these studies is productivity, the rate at which organic matter is produced per area per time (i.e. a function of population density and the growth rates of individuals). Rates of production are informative because they are the rates at which organic matter is made available to higher trophic lev- 
els, and they also reflect the relative importance of organisms as consumers and nutrient recyclers, as rates of all these metabolic processes scale to body mass with a power of $\sim 0.75$ (Peters 1983). The Canadian and South African studies largely ignored the potential contribution of epifauna, but Edgar \& Moore (1986) show that, as a result, a major pathway may have been neglected. Edgar \& Moore applied a literature-derived annual production:biomass ratio to biomass estimates for seaweed epifauna in the Cape Peninsula kelp forest, and calculated that productivity of seaweed epifauna in the mediate zone of the kelp forest comprises about $60 \%$ of the value given by Newell et al. (1982) for larger animals offshore. The relative contribution of the epifauna may be even greater elsewhere, because the dominance of large suspension feeders (such as mussels) in the South African kelp beds is not typical of subtidal rocky reefs in other parts of the world (Edgar \& Moore 1986).

There appear to be 3 main reasons why epifauna have received less attention than the megafauna. First, epifauna are less conspicuous than larger animals such as echinoids, fish, and lobsters. Second, they are more difficult to sample quantitatively from the structurally diverse habitats found on rocky reefs. Third, the diversity of epifaunal assemblages generally precludes the calculation of productivity for each species using conventional methods such as cohort analysis. However, the recent method of Edgar (1990) makes it possible to estimate assemblage-level productivity simply by washing samples through a stack of sieves with geometrically decreasing mesh sizes, and counting the number of individuals trapped on each sieve. Edgar gives an equation that predicts the body mass of individuals on each sieve, and another equation that predicts productivity as a function of body mass and water temperature. The latter equation is based on a compilation of literature-derived data for individual species and is surprisingly precise (log body weight and log water temperature account for $94 \%$ of variation in $\log$ productivity). The error involved in predicting the productivity of individual species using such methods can be high, but tends to cancel out in assemblage-level estimates (Edgar 1990). Brey (1990) found that a similar allometric method generated assemblage-level estimates that were within $11 \%$ of values obtained using cohort-based methods for 3 of the 4 benthic communities he examined.

In this paper I quantify the density, biomass and productivity of reef-dwelling animals $>0.5 \mathrm{~mm}$ sieve size in 4 habitats characteristic of shallow subtidal rocky reefs in temperate northeastern New Zealand. The main objective is to determine the relative contributions of epifauna and megafauna to secondary productivity on the reef.
The study was done in the Cape Rodney to Okakari Point Marine Reserve, which has been under legal protection since 1975 (Gordon \& Ballantine 1976). Habitats within the reserve have been categorised and described by Ayling (1978). These habitats occur on hard substrata along the exposed northeastern coast of New Zealand (Choat \& Schiel 1982), and Ayling's scheme is broadly adhered to in the following introduction of habitats surveyed in this study.

(1) Carpophyllum plumosum var. capillifolium forest (hereafter 'Carpophyllum forest'). This finely structured fucalean seaweed grows to a height of 0.5 to $1.5 \mathrm{~m}$, and forms dense monocultural stands on shallow (0 to $5 \mathrm{~m}$ depth) sandstone platforms. Most of the bedrock is occupied by densely intertwined C. plumosum var. capillifolium holdfasts. This habitat is a component of Ayling's (1978) 'shallow broken rock', which is typically dominated by several species of the endemic New Zealand genus Carpophyllum.

(2) Ecklonia radiata forest (hereafter 'Ecklonia forest'). Dense, 1 to $1.5 \mathrm{~m}$ tall stands of the stipitate kelp E. radiata are a characteristic feature of rocky reefs in northern New Zealand (Choat \& Schiel 1982, Schiel 1988). A variety of substrata including red turfing algae and encrusting corallines are found beneath the canopy of Ecklonia forests (Schiel 1988). The shallow area chosen for this study did not appear to have been affected by the mass mortality of $E$. radiata that occurred in deeper waters during the summer of $1992-$ 93 (Cole \& Babcock 1996).

(3) Urchin barrens. Also known as 'rock flats' (Ayling 1978), 'coralline flats' (Ayling 1981), or 'barren grounds' (Lawrence 1975), this habitat typically forms a zone at 5 to $10 \mathrm{~m}$ depth (Choat \& Schiel 1982), and is defined by high densities of the echinoid Evechinus chloroticus and a suite of grazing gastropods that together eliminate almost all erect seaweeds, leaving a layer of crustose coralline algae (Ayling 1981, Andrew \& Choat 1982).

(4) Coralline algal turf flats (hereafter 'turf flats'). In this habitat (termed 'sediment covered rock flats' by Ayling 1978), articulated corallines form uniform beds on flat rock. The turf traps and stabilises a 10 to $20 \mathrm{~mm}$ thick layer of sand, and also accumulates detritus. The turbinid gastropod Cookia sulcata and the sponge Polymastia sp. are the only conspicuous invertebrates. High densities of juvenile carangid, mullid, and sparid fishes are associated with this habitat, feeding on small animals in the turf (Choat \& Kingett 1982)

In the following text, reference is often made to the structural complexity of the 4 habitats. The Carpophyllum forest and turf flats are considered to be finely structured on a scale relevant to epifauna due to the dense narrow fronds of the dominant plants (Taylor \& Cole 1994). The Ecklonia forest is considered to be a 
less structurally complex environment for epifauna since the fronds of the dominant alga are much wider and flatter (Taylor \& Cole 1994), although the red algal understorey species provide some fine structure. The urchin barrens are held to be the least complex habitat, as the dominant macroalgae (crustose corallines) mould to the bedrock and project very little tissue into the water column.

\section{METHODS}

Density, biomass and productivity of all mobile animals larger than $0.5 \mathrm{~mm}$ sieve size were surveyed within permanent plots set up in 4 subtidal habitats at sites in the Cape Rodney to Okakari Point Marine Reserve, northeastern New Zealand $\left(36^{\circ} 16^{\prime} \mathrm{S}, 174^{\circ}\right.$ $47^{\prime} \mathrm{E}$ ). The habitats are listed in Table 1 ; together they occupy $-71 \%$ of exposed bedrock in the reserve (Ayling 1978). Their depths ranged from 2 to $9 \mathrm{~m}$.

Within each habitat, 200 to $400 \mathrm{~m}^{2}$ of seafloor was delimited using small floats tied to stainless steel pegs that were cemented into the bedrock. One to eight plots (irregular polygons) were set up in each habitat, with the number of plots depending on the patchiness of the habitat. The area within each plot was measured by trilateration amongst the pegs. All sampling and censuses were done within these plots by a diver during daylight hours. Within each habitat, sampling effort was distributed amongst plots in proportion to plot area (i.e. if a plot occupied $25 \%$ of the area of a habitat, then it received $25 \%$ of the sampling effort for that habitat). Quadrats were placed haphazardly within plots.

Sessile animals such as anemones, sponges, ascidians and bryozoans were uncommon, and were not considered except as substrata for epifauna.

Epifauna. Epifauna were sampled from virtually all substrata present (see Table 2).

Animals on sponges and erect seaweeds were sampled by enclosing their individual host organisms in a large plastic bag that had a $0.2 \mathrm{~mm}$ mesh drainhole clamped into one corner. Ecklonia radiata plants were divided into 3 size classes (stipe length $<50 \mathrm{~mm}, 50$ to $200 \mathrm{~mm},>200 \mathrm{~mm}$ ) and were sampled complete with holdfast. Carpophyllum plumosum var. capillifolium stipes were divided into 2 size classes (length $<500 \mathrm{~mm}, \geq 500 \mathrm{~mm}$ ), and were cut off $10 \mathrm{~mm}$ above their holdfasts. Entire sponges were removed by slicing them off at the base with a knife.

Animals on substrata such as Carpophyllum plumosum var. capillifolium holdfasts (after the stipes were removed), coralline turf, bare rock/coralline paint, and rock beneath the echinoid Evechinus chloroticus were sampled from within a sealed circular area of $100 \mathrm{~mm}$ diameter $\left(7.85 \times 10^{-3} \mathrm{~m}^{2}\right)$ using a suction sampler with $0.2 \mathrm{~mm}$ mesh collecting bag attached (Taylor et al. 1995). The suction sampler was also used to sample sand from within a $50 \mathrm{~mm}$ internal diameter $(1.96 \times$ $10^{-3} \mathrm{~m}^{2}$ ) plastic pipe corer. Bedrock in the Carpophyllum forest was 'terraced' such that there were many coralline paint-covered vertical faces, each $\sim 0.1 \mathrm{~m}$ high and 1 to $4 \mathrm{~m}$ long. The suction sampler was used to vacuum animals from $0.1 \mathrm{~m}$ wide sections of those faces.

Five replicate samples were taken of each substratum, except for Carpophyllum plumosum var. capillifolium stipes ( $\mathrm{n}=10$ for each size class), and rock beneath Evechinus chloroticus ( $\mathrm{n}=10$ ).

Epifauna inhabiting Ecklonia radiata and Carpophyllum plumosum var capillifolium plants were removed from their hosts by washing in dilute formalin (Taylor \& Cole 1994). Sponge-dwelling amphipods were individually removed from within their host using a scalpel and forceps (under a dissecting microscope). Samples from all substrata were preserved in $5 \%$ formalin, with Rose Bengal vital stain added to E. radiata and coralline turf samples. Samples were later washed through a $\log$-series of sieves $(8,5.6,4,2.8,2,1.4,1$, 0.71 , and $0.5 \mathrm{~mm}$ mesh sizes) to size-fractionate the animals (Edgar 1990). Megafaunal individuals encountered were dealt with separately (see next section). Epifaunal individuals trapped on each sieve were identified to coarse taxonomic levels and counted, and their biomass and productivity were estimated using the general equations of Edgar (1990).

Table 1. Habitats surveyed for density, biomass and productivity of animals $>0.5 \mathrm{~mm}$ sieve size. Percent coverage of subtidal rock in the Cape Rodney to Okakari Point Marine Reserve, New Zealand, is from Ayling (1978), except for the Carpophyllum forest, which occupied part of Ayling's 'shallow broken rock' habitat (the figure given is my estimate)

\begin{tabular}{|lcccc|}
\hline & Carpophyllum forest & Ecklonia forest & Urchin barrens & Turf flats \\
\hline Coverage of subtidal rock in reserve $(\%)$ & $\sim 5$ & 29.8 & 31.4 & 5.1 \\
Location & Knot Rock & Martins Rock & Waterfall Crest & Goat Is. Bay \\
Depth $(\mathrm{m})$ & $2-4$ & $8-9$ & $6-8$ & 8 \\
Plots $(\mathrm{n})$ & 8 & 1 & 1 & 5 \\
Total area of plots $\left(\mathrm{m}^{2}\right)$ & 231.6 & 380.9 & 400.9 & 196.0 \\
\hline
\end{tabular}


Table 2. Extents of substrata sampled for epifauna

\begin{tabular}{|c|c|c|c|c|}
\hline Substratum & Carpophyllum forest & Ecklonia forest & Urchin barrens & Turf flats \\
\hline E. radiata (<50 mm stipe length) & & 9.6 plants $\mathrm{m}^{-2}$ & & \\
\hline E. radiata (50-200 mm stipu length) & & 1.9 plants $\mathrm{m}^{-2}$ & & \\
\hline E. radiata (>200 $\mathrm{mm}$ stipe length) & & 6.5 plants $\mathrm{m}^{-2}$ & & \\
\hline C. plumosum stipes (<500 $\mathrm{mm}$ length) & 207.9 stipes $\mathrm{m}^{-2}$ & & & \\
\hline C. plumosum stipes ( $\geq 500 \mathrm{~mm}$ length) & 137.3 stipes $\mathrm{m}^{-2}$ & & & \\
\hline C. plumosum holdfast & $76.8 \%$ cover & & & \\
\hline Coralline turf & $5.2 \%$ cover & $44.0 \%$ cover & & $100 \%$ cover \\
\hline Ceramium sp. (red alga) & & 3.1 plants $\mathrm{m}^{-2}$ & & \\
\hline Polymastia sp. (sponge) & & 0.15 sponges $\mathrm{m}^{-2}$ & & 0.85 sponges $\mathrm{m}^{-2}$ \\
\hline Beneath Evechinus chloroticus & & & 4.0 E. chloroticus $\mathrm{m}^{-2}$ & \\
\hline Sand & & $2.5 \%$ cover & & \\
\hline Bare rock/coralline paint & $14.4 \%$ cover & $47.0 \%$ cover & $100 \%$ cover & \\
\hline Vertical rock faces & $0.26 \mathrm{~m} \mathrm{~m}^{-2}$ & & & \\
\hline
\end{tabular}

Results were scaled to account for the prevalence of each substratum, estimated using $0.25 \mathrm{~m}^{2}$ quadrats for Carpophyllum plumosum var, capillifolium stipes in the Carpophyllum forest, and $1 \mathrm{~m}^{2}$ quadrats for Ecklonia radiata, Ceramium sp. (red alga) and Polymastia $\mathrm{sp}$. (sponge) in the Ecklonia forest $(\mathrm{n}=10)$. Total counts were made of Polymastia sp. in the turf flats. Percent cover of substrata on flat surfaces (e.g. bare rock/ coralline paint) was estimated by recording substratum type under points of a $1 \mathrm{~m}^{2}$ grid laid over plots in each habitat using measuring tapes. The total distance of vertical rock faces within the Carpophyllum forest was measured with a tape, so that numbers of animals in suction samples taken from a $0.1 \mathrm{~m}$ width of rock face could be scaled to per $\mathrm{m}^{2}$ of substratum. Extents of the various substrata are given in Table 2 . Total cover sampled was less than $100 \%$ in 2 habitats. In the Carpophyllum forest the remainder consisted of transient sand $(2.5 \%)$ and cobbles $(1.0 \%)$, neither of which held appreciable numbers of epifauna (pers. obs.). In the Ecklonia forest, the remainder was E. radiata holdfasts $(6.0 \%)$ that were sampled with the rest of the plant and scaled to plant density, and Ancorina sp. sponges $(0.5 \%)$ that harboured negligible numbers of epifauna (pers. obs.).

Megafauna. Animals longer than $10 \mathrm{~mm}$ were censused in situ. Sizes of gastropods, hermit crabs and echinoids were measured directly using vernier calipers, but lengths of more mobile animals such as fish and larger decapods had to be estimated visually. Within each habitat, total counts were made of spiny lobsters (Jasus edwardsii) and large fish (excluding pelagic species), the latter replicated 2 to 4 times on separate days. Smaller, cryptic fish (mostly blennioids) and large brachyuran crabs (mostly Plagusia chabrus) were censused within $5 \times 1 \mathrm{~m}$ strip transects $(\mathrm{n}=10)$. Echinoids (Evechinus chloroticus), gastropods (trochids, turbinids and neogastropods) and hermit crabs
(Paguroidea) were censused within $1 \mathrm{~m}^{2}$ quadrats, except in the urchin barrens, where highly abundant individuals of the gastropods Cantharidus purpureus, Cellana stellifera and Trochus viridis were censused within $0.25 \mathrm{~m}^{2}$ quadrats $(\mathrm{n}=10$ ). In the turf flats habitat, total counts were made of all invertebrates $>40 \mathrm{~mm}$ (mostly the large gastropod Cookia sulcata; these individuals were not considered when found in the $1 \mathrm{~m}^{2}$ quadrats). Biomass and productivity of megafaunal individuals encountered during sampling for epifauna (mainly cryptic blennioid and gobiesocid fish and gastropods found on seaweed plants) were estimated as described below, and scaled per $\mathrm{m}^{2}$ of seabed according to the extent of the substratum, as described earlier for epifauna.

Biomass and productivity values were expressed as ash-free dry weight (AFDW), the difference between animal (shell-free) dry weight (after drying to constant weight at $80^{\circ} \mathrm{C}$ ) and inorganic weight (after incinerating the dry tissue at $500^{\circ} \mathrm{C}$ for $12 \mathrm{~h}$ (most megainvertebrates) or $24 \mathrm{~h}$ (fish), or after boiling it for $1 \mathrm{~h}$ in $10 \%$ w/v NaOH (echinoids) (Crisp 1984)].

Biomasses were estimated using length-weight relationships determined from animals collected outside the study sites. Fish length-wet weight equations were taken from Taylor \& Willis (1998), Coefficients for length-AFDW equations for megainvertebrates are given in Table 3

Growth in length of individual fishes was estimated using the von Bertalanffy growth formula (VBGF):

$$
L_{t}=L_{\infty}\left(1-\mathrm{e}^{-K\left(t-i_{0}\right)}\right)
$$

where $L_{t}=$ length at age $t_{1} L_{\infty}=$ asymptotic length, $K=$ the von Bertalanffy growth constant, and $t_{0}=$ the theoretical age at length zero. $L_{\infty}$ and $K$ were taken from the literature wherever possible (compiled in Taylor \& Willis 1998). When such data were unavailable for a species, they were estimated using regression equa- 
Table 3. Equations relating ash-free dry weight (AFDW) to linear body dimension for megainvertebrates, and the von Bertalanffy growth parameters $L_{\infty}$ and $K$ where available. $W=a L^{b}$, where $W=\operatorname{AFDW}(\mathrm{g})$, and $L=$ linear body dimension (mm). Taxa: $B=$ brachyuran crab, $\mathrm{E}=$ echinoid, $\mathrm{G}=$ gastropod, $\mathrm{HC}=$ hermit crab, $\mathrm{SL}=$ spiny lobster. Linear body dimensions: AL = aperture length, $\mathrm{CL}=$ carapace length, $\mathrm{CW}=$ carapace width, $\mathrm{D}=$ test diameter, $\mathrm{H}=$ height (axis of the spire), $\mathrm{L}=$ length (tip of spire to outermost point of aperture), $\mathrm{SL}=$ shell length, $\mathrm{W}=$ width (perpendicular to the axis of the spire). The correction factor of Snowdon (1991) is a scaling factor used to derive an arithmetic mean from the geometric mean predicted by the length-weight power curve after back-transforming a least squares regression on log-log data. Sources: (1) West (1991); (2) Hartley (1978); (3) Walker (1981); (4) Saila et al. (1978)

\begin{tabular}{|c|c|c|c|c|c|c|c|c|c|c|}
\hline Taxon & $\begin{array}{l}\text { Linear body } \\
\text { dimension }\end{array}$ & a & $b$ & $\begin{array}{c}\text { Correction } \\
\text { factor of } \\
\text { Snowdon } \\
(1991)\end{array}$ & $\begin{array}{l}\text { Coeff. of } \\
\text { determin- } \\
\text { ation } \\
\left(r^{2}\right)\end{array}$ & $\mathrm{n}$ & $\begin{array}{l}\text { Length } \\
\text { range } \\
\text { (mm) }\end{array}$ & $\begin{array}{c}L_{\infty} \\
(\mathrm{mm})\end{array}$ & K & $\begin{array}{c}\text { Source } \\
\text { for } L_{\infty} \\
\text { and } \\
K\end{array}$ \\
\hline Buccinulum spp. (G) & AL & $3.964 \times 10^{-5}$ & 2.9096 & 1.0664 & 0.818 & 16 & $11-23$ & & & \\
\hline Calliostoma punctulatum (G) & $\mathrm{H}$ & $7.116 \times 10^{-6}$ & 3.4078 & 1.0116 & 0.992 & 20 & $12-32$ & 37 & 0.71 & (1) \\
\hline Cantharidus purpureus (G) & $\mathrm{H}$ & $1.774 \times 10^{-3}$ & 2.7903 & 0.9923 & 0.909 & 20 & $7-25$ & 19 & 2.60 & (2) \\
\hline Cellana stellifera $(G)$ & $\mathrm{L}$ & $2.149 \times 10^{-6}$ & 3.3899 & 1.0178 & 0.971 & 21 & $13-40$ & 40 & 0.84 & (2) \\
\hline Cookia sulcata (G) & $\mathrm{L}$ & $2.153 \times 10^{-5}$ & 2.9192 & 1.0090 & 0.994 & 23 & $18-85$ & & & \\
\hline Dicathais orbita (G) & $\mathrm{AL}$ & $8.596 \times 10^{-6}$ & 3.2809 & 1.0701 & 0.941 & 23 & $16-50$ & & & \\
\hline Evechinus chloroticus (E) & D & $6.550 \times 10^{-4}$ & 2.1835 & 0.9907 & 0.987 & 17 & $13-95$ & 92 & 0.16 & (3) \\
\hline Jasus edwardsii (SL) & $C L$ & $7.551 \times 10^{-4}$ & 2.5291 & 0.9933 & 0.985 & 20 & $50-188$ & & & \\
\hline J. edwardsii (SL) (male) & $C L$ & & & & & & & 187 & 0.09 & (4) \\
\hline J. edwardsii (SL) (female) & $\mathrm{CL}$ & & & & & & & 117 & 0.16 & (4) \\
\hline Maoricolpus roseus (G) & $\mathrm{L}$ & $8.111 \times 10^{-6}$ & 2.5174 & 1.0036 & 0.910 & 18 & $56-76$ & & & \\
\hline Paguroidea $(\mathrm{HC})$ & $\mathrm{SL}$ & $7.208 \times 10^{-5}$ & 2.2261 & 1.1590 & 0.556 & 18 & $13-45$ & & & \\
\hline Plagusia chabrus (B) & $\mathrm{CW}$ & $1.162 \times 10^{-4}$ & 2.9224 & 1.0339 & 0.984 & 21 & $8-58$ & & & \\
\hline Trochus viridis (G) & W & $9.473 \times 10^{-8}$ & 4.8496 & 1.0067 & 0.916 & 22 & $14-23$ & 20 & 2.44 & (2) \\
\hline Turbo smaragdus (G) & W & $1.747 \times 10^{-5}$ & 3.0695 & 0.9721 & 0.991 & 20 & $7-31$ & & & \\
\hline
\end{tabular}

tions in Taylor \& Willis (1998), with $L_{c o}$ estimated as a function of the lower length value given for adult individuals in Ayling \& $\operatorname{Cox}(1982)$, and wet weight at $L_{\infty}$ then used to predict $K$. Growth in length was converted to growth in AFDW using length-wet weight relationships from Taylor \& Willis (1998), and a wet weight-AFDW conversion factor of 0.202 , estimated by drying and ashing single individuals of 18 fish species ranging in size from 0.61 to $4600 \mathrm{~g}$ wet weight (Taylor 1997). This procedure estimated the average annual growth of fish. Seasonality of growth was accounted for by using a seasonally oscillating form of the VBGF:

$$
L_{t}=L_{\infty}\left(1-\mathrm{e}^{-\left|K\left(t-t_{0}\right)+\frac{C K}{2 \pi} \sin 2 \pi\left(t-t_{5}\right)\right|}\right)
$$

where $C=$ the amplitude of the oscillation and $t_{S}=$ phase (Pauly \& David 1981). Eq. (2) cannot be used to estimate growth in length directly, since an individual fish of given length is unlikely to be of the exact age specified by the equation. Instead, a multiplier is required that expresses, for any given time of the year, the seasonal growth rate relative to the annual average growth rate. This multiplier is equal to the slope of the seasonal VBGF divided by the slope of the ordinary VBGF. The derivative of length with respect to time in the seasonally oscillating $\operatorname{VBGF}(E q .2)$ is:

$$
\frac{\mathrm{d} L_{t}}{\mathrm{~d} t}=K L_{\infty}\left[1+C \cos 2 \pi\left(t-t_{s}\right)\right] \mathrm{e}^{-\left[K\left(t-t_{0}\right)+\frac{C K}{2 \pi} \sin 2 \pi\left(t-t_{s}\right)\right]}
$$

The derivative of length with respect to time in the ordinary VBGF (Eq. 1) is:

$$
\frac{\mathrm{d} L_{t}}{\mathrm{~d} t}=K L_{\infty}^{-K\left(t-t_{0}\right)}
$$

The ratio of slopes, $R$, (i.e. the instantaneous growth rate relative to the average annual value) is Eq. (3) divided by Eq. (4):

$$
R=\left[1+C \cos 2 \pi\left(t-t_{S}\right)\right] \mathrm{e}^{\left.-1 \frac{C K}{2 \pi} \sin 2 \pi\left(t-t_{s}\right)\right]}
$$

On a global scale, $C$, the amplitude term in the seasonal VBGF, is strongly positively correlated with the difference between mean monthly summer and winter water temperatures $(\Delta T)$, with $C=0.113 \Delta T$ (Longhurst \& Pauly 1987). In the Cape Rodney to Okakari Point Marine Reserve, long-term average monthly minimum and maximum sea surface temperatures (SSTs) are 14.0 and $20.6^{\circ} \mathrm{C}$ respectively (Evans 1992). The difference of $6.6^{\circ} \mathrm{C}$ is predicted to result in seasonally oscillating growth with an amplitude $(C)$ of 0.75 (Longhurst \& Pauly 1987). By means of comparison, the only empirical value of $C$ that I could locate for the region is 0.85 , for combined 1985-89 juvenile year classes of the snapper, Pagrus auratus (Francis 1994). For the present study, I used Francis's mean phase $\left(t_{s}\right)$ of $\sim 0.03 \mathrm{yr}$ (theoretical birthdate of January 1) in Eq. (5). Average annual productivity values calculated using Eq. (1) were scaled for seasonal variability in growth using the 
ratio in Eq. (5) to yield an estimated productivity for the survey time.

Productivity of megainvertebrates was estimated as for fishes, except that $L_{\infty}$ was estimated from the length of the largest individual collected for the lengthweight relationships $\left(L_{\max }\right)$, where $L_{\infty}=1.0 L_{\max }\left(\mathrm{r}^{2}=\right.$ $0.997)$. $K$ was estimated using the following regression equation, based on data from Table $3: K=0.823 \times$ $\left(A F D W_{L_{\infty}}\right)^{-0.415}$, where AFDW $L_{L_{\infty}}$ is ash-free dry weight at $L_{\infty}(\mathrm{g} A F D W)\left[r^{2}=0.914\right.$, correction factor of Snowdon $(1991)=1.0991]$.

Fishes were categorised according to their major food source as (1) herbivores, (2) predators of epifauna, (3) predators of megafauna, or (4) predators of sessile animals (from references in Jones 1988). Consumption rates of fishes that prey upon epifauna were estimated in 2 different ways: (1) by applying an assumed conversion efficiency of $10 \%$ (Pauly \& Christensen 1995) to fish productivity data (from Table 7), and (2) by applying a daily consumption rate of $3.1 \%$ of fish body weight (Edgar \& Shaw 1995) to fish biomass data (from Table 6). These consumption rates were then expressed as a percentage of (1) total epifaunal productivity and (2) productivity of crustaceans $>1 \mathrm{~mm}$ sieve size (the primary food source for fish of 0.1 to $100 \mathrm{~g}$ wet weight; Edgar \& Shaw 1995).

Seasonality. All 4 habitats were surveyed once, as described above, during October-November 1994 (austral spring). Productivity values for megafauna were calculated for the common date of October 15, which corresponded to 0.789 as a fraction of the year (to substitute for $t$ in Eq. 5). Productivity values for epifauna were also calculated for October 15, using the Goat Island 25 yr mean SST for this date of $15.3^{\circ} \mathrm{C}$ (Evans 1992) in the equation of Edgar (1990) (his Eq. 1 in Table V).

Plans to survey all 4 habitats seasonally for 1 yr turned out to be logistically impractical. Instead, a single habitat, the turf flats, was resurveyed during each of the 3 seasons following spring 1994, in order to examine variability in density, biomass, and secondary productivity throughout the year. Productivity for each season was calculated based on the actual dates and SSTs at sampling.

To allow comparisons to be made with literature values for secondary productivity in other aquatic habitats, the daily production value for each of the 3 habitats measured once in spring was converted to an annual estimate using the following equation

$$
\mathrm{AP}_{h}=\mathrm{SP}_{h} \times 365 \times \mathrm{AP}_{l} / \mathrm{SP}_{l}
$$

where $A P_{h}=$ estimated annual production in habitat $h$, $\mathrm{SP}_{h}=$ daily production in habitat $h$ during spring, $\mathrm{AP}_{t}=$ average annual daily production in the turf flats habitat (i.e. the average of the 4 seasonal values), and $\mathrm{SP}_{t}=$ daily production in the turf flats habitat during spring. Separate factors were calculated for epifauna and megafauna. The same procedure was also carried out for density and biomass.

Reef-wide annual density, biomass and productivity. Estimates of average annual density, biomass and productivity were scaled to give single reef-level values according to values provided by Ayling (1978) for percent cover of subtidal rock in the marine reserve (Table 1). The 4 habitats sampled covered a total of $-71.3 \%$ of subtidal rock in the marine reserve, and it was assumed that the reef-level values for density, biomass and productivity were equivalent for fauna in habitats comprising the remaining $28.7 \%$. This may have resulted in a slight overestimation of reef-level density, biomass and productivity if these values were negatively correlated with water depth, as none of the 4 habitats surveyed was deeper than $9 \mathrm{~m}$, and the reef often extends to 15-18 $\mathrm{m}$ depth (Ayling 1978).

Standard errors. Standard errors presented in this paper are based on variability amongst final estimates of density, biomass and productivity calculated for each sample (or quadrat or transect). Where necessary, errors were compounded following Topping (1962). The errors are exact for the density estimates, but the errors on the biomass and productivity estimates do not incorporate variability due to (1) error in estimating animal lengths in the field, or (2) variance in relationships amongst length, weight and growth parameters.

\section{RESULTS}

\section{Density}

Epifauna comprised the overwhelming majority $(>99.6 \%)$ of individual animals $>0.5 \mathrm{~mm}$ sieve size in all 4 habitats (Table 4). Densities were positively correlated with the apparent structural complexity of the habitats, being highest in the Carpophyllum forest $\left(2.0 \times 10^{5}\right.$ ind $\left.\mathrm{m}^{-2}\right)$, and lowest in the urchin barrens $\left(2.4 \times 10^{4}\right.$ ind $\left.\mathrm{m}^{-2}\right)$. Grazing gastropods (Calliostoma punctulatum, Cantharidus purpureus, Cellana stellifera, Cookia sulcata, Trochus viridis, Turbo smaragdus; Creese 1988, West 1991) were the next most abundant group, reaching densities of 50 to $60 \mathrm{ind} . \mathrm{m}^{-2}$ in the Ecklonia forest and the urchin barrens. Densities of fish and megainvertebrates such as decapods (mostly Jasus edwardsii and Plagusia chabrus), echinoids, and neogastropods (Buccinulum spp., Dicathais orbita) were generally in the order of 0.01 to 10 ind. $\mathrm{m}^{-2}$.

Epifaunal assemblages tended to be dominated numerically by gastropods and gammarid amphipods, with 1 of these 2 being the most abundant taxon on 12 of the 15 substrata sampled (Table 5). Polychaetes, 
Table 4. Density (ind. $\mathrm{m}^{-2}$ ) of anumals $>0.5 \mathrm{~mm}$ sieve size in 4 subtidal rocky reef habitats in northeastern New Zealand

\begin{tabular}{|c|c|c|c|c|c|c|c|c|c|c|c|c|}
\hline \multirow[t]{2}{*}{ Taxon } & \multicolumn{3}{|c|}{ Carpophyllum forest } & \multicolumn{3}{|c|}{ Ecklonia forest } & \multicolumn{3}{|c|}{ Urchin barrens } & \multicolumn{3}{|c|}{ Turf flats } \\
\hline & Mean & $(1 \mathrm{SE})$ & $\%$ & Mean & (1 SE) & $\%$ & Mean & (1 SE) & $\%$ & Mean & $(1 \mathrm{SE})$ & $\%$ \\
\hline \multicolumn{13}{|l|}{ Fish } \\
\hline Feeding on seaweeds & 0.014 & $(0.004)$ & 0.0000 & & & & & & & & & \\
\hline Feeding on epifauna & 2.864 & $(2.497)$ & 0.0014 & 4.609 & $(1.850)$ & 0.0065 & 3.700 & $(0.755)$ & 0.0151 & 0.080 & $(0.075)$ & 0.0001 \\
\hline Feeding on megafauna & 0.012 & $(0.003)$ & 0.0000 & 0.007 & $(0.003)$ & 0.0000 & 0.012 & $(0.000)$ & 0.0001 & 0.007 & $(0.007)$ & 0.0000 \\
\hline $\begin{array}{l}\text { Feeding on sessile } \\
\text { animals }\end{array}$ & & & & 0.002 & $(0.002)$ & 0.0000 & 0.004 & $(0.001)$ & 0.0000 & 0.003 & $(0.003)$ & 0.0000 \\
\hline Spiny lobsters & & & & 0.018 & $(0.000)$ & 0.0000 & & & & & & \\
\hline Brachyuran crabs & 0.12 & $(0.05)$ & 0.0001 & 1.40 & $(0.97)$ & 0.0020 & 0.14 & $(0.07)$ & 0.0006 & & & \\
\hline Hermit crabs & 1.90 & $(0.60)$ & 0.0009 & 2.30 & $(0.92)$ & 0.0032 & 1.60 & $(1.22)$ & 0.0065 & 1.61 & $(0.56)$ & 0.0010 \\
\hline Echinoids & 0.40 & $(0.40)$ & 0.0002 & 2.58 & $(1,60)$ & 0.0036 & 4.00 & $(0.60)$ & 0.0164 & & & \\
\hline \multicolumn{13}{|l|}{ Grazing gastropods } \\
\hline On seafloor & 2.20 & $(0.92)$ & 0.0011 & 15.60 & (1.97) & 0.0219 & 62.00 & $(10.20)$ & 0.2538 & 0.08 & $(0.00)$ & 0.0001 \\
\hline $\begin{array}{l}\text { On seaweeds } \\
\text { guspension-feeding } \\
\text { gastropods }\end{array}$ & & & & 33.54 & $(0.13)$ & $0.04+2$ & & & & 0.40 & $(0.16)$ & 0.0003 \\
\hline Neogastropods & 1.70 & $(0.45)$ & 0.0008 & 2.90 & $(0.48)$ & 0.0041 & 7.90 & $(2.60)$ & 0.0323 & 4.21 & $(1.06)$ & 0.0026 \\
\hline Epifauna & 203301 & (31682) & 99.995 & 71059 & (8403) & 99.911 & 24349 & $(5462)$ & 99.675 & 159080 & (13515) & 99.996 \\
\hline Total & 203310 & $(31682)$ & & 71122 & $(8403)$ & & 24428 & $(5462)$ & & 159086 & $(13515)$ & \\
\hline
\end{tabular}

Table 5. Percentage composition of epifaunal assemblages on substrata within 4 subtidal rocky reef habitats. Totals are averages calculated for each habitat, weighted by the relative densities of total epifauna on each substratum (last column). Reef-level values are the habitat averages scaled according to the relative extents of the habitats (from Table 1). Taxa are ranked in decreasing order of reef-level density. Gast. = gastropod, Gamm. = gammarid amphipod, Poly. = polychaete, Ostr. = ostracod, Tana. = tanaid, Iso. = isopod, Biv = bivalve, Harp. = harpacticold copepod, Nem. = nematode, Cuma. = cumacean, Ophi. = ophiuroid, Capr = caprellid amphipod. Taxa not tabulated comprised $<3 \%$ of total epifaunal individuals for any substratum

\begin{tabular}{|c|c|c|c|c|c|c|c|c|c|c|c|c|c|}
\hline Substratum & Gast. & Gamm. & Poly. & Ostr. & Tana. & Iso. & Biv. & Harp. & Nem. & Cuma. & Ophi. & Capr. & $\begin{array}{l}\text { Density } \\
\text { (ind } \mathrm{m}^{-2} \text { ) }\end{array}$ \\
\hline \multicolumn{14}{|l|}{ Carpophyllum forest } \\
\hline C. plumosum stipes & 9.3 & 78.5 & 1.8 & & 1.1 & 7.7 & 0.02 & 0.6 & 0.1 & & 0.004 & 0.2 & 139124 \\
\hline C. plumosum holdfast & 19.7 & 22.6 & 24.5 & 9.6 & 1.4 & 3.5 & 12.7 & 0.03 & 0.9 & 3.5 & 0.3 & 0.1 & 53613 \\
\hline Coralline turf & 28.5 & 10.8 & 26.9 & 6.1 & 0.8 & 3.8 & 16.6 & 0.03 & 1.2 & 4.4 & 0.1 & 0.1 & 9563 \\
\hline Bare rock/coralline paint & 33.1 & 22.8 & 21.7 & 7.2 & 1.2 & 2.4 & 7.1 & 0.6 & 0.9 & 0.6 & & & 820 \\
\hline Vertical rock faces & 40.3 & 23.9 & 8.1 & 8.5 & 1.3 & 5.9 & 5.7 & & & 3.0 & 0.8 & 0.5 & 182 \\
\hline Total & 13.0 & 60.3 & 9.1 & 2.9 & 1.2 & 6.4 & 4.2 & 0.4 & 0.3 & 1.1 & 0.1 & 0.2 & 203301 \\
\hline \multicolumn{14}{|l|}{ Ecklonia forest } \\
\hline Ecklonia radiata & 3.7 & 27.4 & 19.3 & 2.4 & 2.7 & 8.0 & 8.2 & 15.6 & 4.7 & 0.5 & 5.4 & 0.03 & 9511 \\
\hline Coralline turf & 20.1 & 26.2 & 19.7 & 12.5 & 9.6 & 1.9 & 4.4 & 0.2 & 1.1 & 1.7 & 1.1 & 0.1 & 52329 \\
\hline Ceramium sp. (red alga) & 1.7 & 78.6 & 11.1 & 0.1 & 0.9 & 2.1 & 0.1 & 0.04 & 0.1 & 0.04 & 0.04 & 4.2 & 1212 \\
\hline Polymastia sp. (sponge) & & 97.9 & 0.1 & & & 0.1 & 1.0 & 0.6 & & 0.02 & 0.1 & & 46 \\
\hline Sand & 4.9 & 17.5 & 5.7 & 133 & 4.6 & 1.3 & 3.9 & 0.1 & 37.7 & 10.3 & & 0.1 & 2014 \\
\hline Bare rock/coralline paint & 21.1 & 29.3 & 18.4 & 4.5 & 4.1 & 4.6 & 5.5 & 1.3 & 1.9 & 2.9 & 4.6 & 0.2 & 5947 \\
\hline Total & 17.2 & 27.3 & 1.9 .0 & 10.3 & 7.9 & 2.9 & 4.9 & 2.4 & 2.7 & 1.8 & 1.9 & 0.2 & 71059 \\
\hline \multicolumn{14}{|l|}{ Urchin barrens } \\
\hline $\begin{array}{l}\text { Beneath Evechinus } \\
\text { chloroticus }\end{array}$ & & & & & & 00.0 & & & & & & & 18 \\
\hline Bare rock/coralline paint & 50.1 & 17.5 & 14.2 & 4.8 & 2.4 & 4.1 & 1.6 & 1.5 & 0.3 & 0.2 & 0.4 & 0.9 & 24331 \\
\hline Total & 50.1 & 17.5 & 14.2 & 4.8 & 2.4 & 4.2 & 1.6 & 1.5 & 0.3 & 0.2 & 0.4 & 0.9 & 24349 \\
\hline \multicolumn{14}{|l|}{ Turf flats } \\
\hline Coralline turf & 4.0 & 45.3 & 30.9 & 7.8 & 1.9 & 3.2 & 1.5 & 0.3 & 2.8 & 0.9 & 0.3 & 0.3 & 159006 \\
\hline Polymastia sp. (sponge) & 2.4 & 86.5 & 4.6 & & 1.1 & 1.6 & & & 2.1 & 0.1 & & & 74 \\
\hline Total & 4.0 & 45.3 & 30.9 & 7.8 & 1.9 & 3.2 & 1.5 & 0.3 & 2.8 & 0.9 & 0.3 & 0.3 & 159080 \\
\hline Reef-level & 30.4 & 26.6 & 17.0 & 7.2 & 4.6 & 3.7 & 3.2 & 1.7 & 1.5 & 1.0 & 1.0 & 0.5 & 66058 \\
\hline
\end{tabular}


Table 6. Biomass (g AFDW $\mathrm{m}^{-2}$ ) of animals $>0.5 \mathrm{~mm}$ sieve size in 4 subtidal rocky reef habitats

\begin{tabular}{|c|c|c|c|c|c|c|c|c|c|c|c|c|}
\hline \multirow[t]{2}{*}{ Taxon } & \multicolumn{3}{|c|}{ Carpophyllum forest } & \multicolumn{3}{|c|}{ Ecklonia forest } & \multicolumn{3}{|c|}{ Urchin barrens } & \multicolumn{3}{|c|}{ Turf flats } \\
\hline & Mean & $(1 \mathrm{SE})$ & $\%$ & Mean & (1 SE) & $\%$ & Mean & $(1 \mathrm{SE})$ & $\%$ & Mean & (1 SE) & $\%$ \\
\hline \multicolumn{13}{|l|}{ Fish } \\
\hline Feeding on seaweeds & 0.67 & $(0.66)$ & 2.1 & & & & & & & & & \\
\hline Feeding on epifauna & 0.59 & $(0.33)$ & 1.9 & 1.60 & $(0.51)$ & 7.5 & 0.42 & $(0.09)$ & 1.0 & 0.39 & $(0.39)$ & 1.5 \\
\hline Feeding on megafauna & 0.29 & $(0.10)$ & 0.9 & 0.31 & $(0.18)$ & 1.4 & 0.34 & $(0.05)$ & 0.8 & 0.10 & $(0.10)$ & 0.4 \\
\hline $\begin{array}{l}\text { Feeding on sessile } \\
\text { animals }\end{array}$ & & & & 0.06 & $(0.06)$ & 0.3 & 0.16 & $(0.07)$ & 0.4 & 0.12 & $(0.12)$ & 0.5 \\
\hline Spiny lobsters & & & & 1.48 & $(0.00)$ & 6.9 & & & & & & \\
\hline Brachyuran crabs & 0.18 & $(0.07)$ & 0.6 & 1.02 & $(0.56)$ & 4.8 & 0.09 & $(0.06)$ & 0.2 & & & \\
\hline Hermit crabs & 0.10 & $(0.03)$ & 0.3 & 0.12 & $(0.05)$ & 0.6 & 0.30 & $(0.25)$ & 0.7 & 0.07 & $(0.03)$ & 0.3 \\
\hline Echinoids & 1.46 & $(1,46)$ & 4.6 & 0.22 & $(0.14)$ & 1.0 & 24.73 & $(3.98)$ & 58.6 & & & \\
\hline \multicolumn{13}{|l|}{ Grazing gastropods } \\
\hline $\begin{array}{l}\text { On seafloor } \\
\text { On seaweeds }\end{array}$ & 1.19 & $(0.63)$ & 3.7 & 2.59 & $(0.48)$ & 12.1 & 11.08 & $(1.60)$ & 26.3 & 0.39 & $(0.00)$ & 1.5 \\
\hline $\begin{array}{l}\text { Suspension-feeding } \\
\text { gastropods }\end{array}$ & & & & & $(0.3 f)$ & & & & & 0.02 & $(0.01)$ & 0.1 \\
\hline Neogastropods & 0.04 & $(0.02)$ & 0.1 & 0.06 & $(0.01)$ & 0.3 & 0.34 & $(0.09)$ & 0.8 & 0.07 & $(0.02)$ & 0.3 \\
\hline Epifauna & 27.19 & $(4.59)$ & 85.8 & 11.24 & $(1.14)$ & 52.8 & 4.71 & $(0.89)$ & 11.2 & 25.26 & $(5.36)$ & 95.6 \\
\hline Total & 31.70 & $(4.92)$ & & 21.30 & $(1.58)$ & & 42.16 & $(4.39)$ & & 26.42 & $(5.38)$ & \\
\hline
\end{tabular}

ostracods, tanaids, isopods, and bivalves were also common across a range of substrata. Taxa that were uncommon overall, but relatively abundant on a single substratum, were harpacticoid copepods (Ecklonia radiata plants), and nematodes and cumaceans (sand).

\section{Biomass}

Biomasses of the different animal groups were more equitable (Table 6). Epifauna comprised 85 to $95 \%$ of total biomass in the Carpophyllum forest and turf flats habitats, $53 \%$ in the Ecklonia forest, and $11 \%$ in the urchin barrens. In the Ecklonia forest, the other $47 \%$ of biomass comprised mostly grazing gastropods, fish preying upon epifauna (mainly the morwong Cheilodactylus spectabilis), and decapods (spiny lobsters and brachyuran crabs). In the urchin barrens, most of the biomass was found in echinoids (59\%) and grazing gastropods $(26 \%)$. Total biomass varied relatively little across the 4 habitats (range $=21$ to $42 \mathrm{~g} \mathrm{AFDW} \mathrm{m}^{-2}$ ), being highest on the urchin barrens.

\section{Productivity}

In the structurally complex vegetated habitats (Carpophyllum forest and turf flats), epifauna contributed 98 to $99 \%$ of total secondary productivity (Table 7 ). The epifaunal contribution was $84 \%$ in the Ecklonia forest, where the only other significant contributions to productivity were made by grazing gastropods (7\%) and fish preying upon epifauna (4\%). Epifaunal productivity was lowest (54\% of the total) in the urchin barrens, where grazing gastropods $(24 \%)$, fish preying upon epifauna (10\%), and echinoids $(8 \%)$ made their greatest contributions to productivity in any habitat.

As with density, total productivity was positively correlated with the structural complexity of the habitat, being highest in the Carpophyllum forest (482 $\mathrm{mg}$ AFDW $\mathrm{m}^{-2} \mathrm{~d}^{-1}$ ), and lowest in the urchin barrens $(117 \mathrm{mg}$ AFDW $\mathrm{m}^{-2} \mathrm{~d}^{-1}$ ). In each habitat the most productive fish feeding guild was the predators of epifauna.

Epifaunal productivity was highest on finely structured vegetated substrata, such as Carpophyllum plumosum var. capillifolium stipes and coralline turf (Table 8). This was most apparent in the Ecklonia forest, where epifaunal productivity was higher in the coralline turf than on the more conspicuous, but flatbladed, Ecklonia radiata plants themselves. Productivity of crustaceans $>1 \mathrm{~mm}$ sieve size amounted to $50 \%$ of total epifaunal productivity in the Carpophyllum forest, and 15 to $19 \%$ in the other habitats (Table 8). Crustaceans $>1$ mm sieve size contributed the highest percentages (40 to $100 \%$ ) of epifaunal production in habitats that were very sheltered (in sponges and beneath Evechinus chloroticus) or finely structured (Carpophyllum plumosum var. capillifolium stipes). The contribution was much lower on bare rock/coralline paint ( 7 to $15 \%$ ) and coralline turf ( 19 to $24 \%$ ).

The proportion of total epifaunal production consumed by fish was estimated to be less than $10 \%$ in the 
Table 7. Productivity ( $\mathrm{mg}$ AFDW $\mathrm{m}^{-2} \mathrm{~d}^{-1}$ ) of animals $>0.5 \mathrm{~mm}$ sieve size in 4 subtidal rocky reef habitats

\begin{tabular}{|c|c|c|c|c|c|c|c|c|c|c|c|c|}
\hline \multirow[t]{2}{*}{ Taxon } & \multicolumn{3}{|c|}{ Carpophyllum forest } & \multicolumn{3}{|c|}{ Ecklonia forest } & \multicolumn{3}{|c|}{ Urchin barrens } & \multicolumn{3}{|c|}{ Turf flats } \\
\hline & Mean & (1 SE) & $\%$ & Mean & $(1 \mathrm{SE})$ & $\%$ & Mean & (1 SE) & $\%$ & Mean & (1 SE) & $\%$ \\
\hline \multicolumn{13}{|l|}{ Fish } \\
\hline Feeding on seaweeds & 0.63 & $(0.54)$ & 0.1 & & & & & & & & & \\
\hline Feeding on epifauna & 2.98 & $(0.90)$ & 0.6 & 9.02 & $(2.03)$ & 4.3 & 11.43 & $(2.14)$ & 9.7 & 2.98 & $(2.96)$ & 0.7 \\
\hline Feeding on megafauna & 0.58 & $(0.20)$ & 0.1 & 0.28 & $(0.17)$ & 0.1 & 0.39 & $(0.03)$ & 0.3 & 0.25 & $(0.25)$ & 0.1 \\
\hline $\begin{array}{l}\text { Feeding on sessile } \\
\text { animals }\end{array}$ & & & & 0.14 & $(0.14)$ & 0.1 & 0.31 & $(0.11)$ & 0.3 & 0.27 & $(0.27)$ & 0.1 \\
\hline Spiny lobsters & & & & 0.42 & $(0.00)$ & 0.2 & & & & & & \\
\hline Brachyuran crabs & 0.56 & $(0.23)$ & 0.1 & 3.95 & $(2.57)$ & 1.9 & 0.30 & $(0.15)$ & 0.3 & & & \\
\hline Hermit crabs & 1.36 & $(0.42)$ & 0.3 & 1.54 & $(0.60)$ & 0.7 & 1.06 & $(0.77)$ & 0.9 & 1.03 & $(0.37)$ & 0.2 \\
\hline Echinoids & 1.15 & $(1.15)$ & 0.2 & 2.05 & $(1.28)$ & 1.0 & 9.43 & $(1.51)$ & 8.0 & & & \\
\hline \multicolumn{13}{|l|}{ Grazing gastropods } \\
\hline On seafloor & 2.44 & $(0.90)$ & 0.5 & $\begin{array}{l}9.76 \\
5.17\end{array}$ & $(1.34)$ & $\begin{array}{l}4.7 \\
2.5\end{array}$ & 27.98 & $(3,76)$ & 23.8 & 0.28 & $(0.00)$ & 0.1 \\
\hline $\begin{array}{l}\text { Suspension-feeding } \\
\text { gastropods }\end{array}$ & & & & & & & & & & 0.26 & $(0.11)$ & 0.1 \\
\hline Neogastropods & 0.66 & $(0.16)$ & 0.1 & 1.00 & $(0.23)$ & 0.5 & 2.55 & $(0.65)$ & 2.2 & 1.15 & $(0.27)$ & 0.3 \\
\hline Epifauna & 472.00 & $(76.10)$ & 97.9 & 174.20 & $(17.70)$ & 83.9 & 63.90 & $(11.50)$ & 54.5 & 413.60 & $(67.10)$ & 98.5 \\
\hline Total & 482.35 & $(76.12)$ & & 207.53 & $(18.15)$ & & 117.35 & $(12.42)$ & & 419.83 & $(67.17)$ & \\
\hline
\end{tabular}

Table 8. Productivity ( $\mathrm{mg} \mathrm{AFDW} \mathrm{m}^{-2} \mathrm{~d}^{-1}$ ) of epifauna on substrata within 4 subtidal rocky reef habitats. $\%_{1}=$ percentage of total productivity for habitat, $\%_{2}=$ percentage of productivity contributed by crustaceans $>1 \mathrm{~mm}$ sieve size (the primary prey for small fish)

\begin{tabular}{|c|c|c|c|c|c|c|c|c|c|c|}
\hline \multirow[t]{2}{*}{ Substratum } & \multicolumn{3}{|c|}{ Carpophyllum forest } & \multicolumn{3}{|c|}{ Eckloma forest } & \multicolumn{2}{|c|}{ Urchin barrens } & \multicolumn{2}{|l|}{ Turf flats } \\
\hline & Mean (1SE) & $\%_{1}$ & $\%_{2}$ & Mean (1SE) & $\%$ & $\%_{2}$ & Mean (1SE) $\%_{1}$ & $\%_{2}$ & Mean (1SE) $\%_{1}$ & $\%_{2}$ \\
\hline $\begin{array}{l}\text { Eckloma radiata } \\
\text { (entire plant) }\end{array}$ & & & & $40.8 \quad(5.4)$ & 23.4 & 12.4 & & & & \\
\hline $\begin{array}{l}\text { Carpophyllum plumosum } \\
\text { stipes }\end{array}$ & $294.0(69.5)$ & 62.3 & 58.2 & & & & & & & \\
\hline $\begin{array}{l}\text { Carpophyllum plumosum } \\
\text { holdfast }\end{array}$ & $156.1(30.8)$ & 33.1 & 37.9 & & & & & & & \\
\hline Coralline turf & $19.4 \quad(3.1)$ & 4.1 & 23.7 & $104.7(15.6)$ & 60.1 & 21.2 & & & $413.4(67.1) 100.0$ & 19.1 \\
\hline Ceramium sp. (red alga) & & & & 2.1 & 1.2 & 34.9 & & & & \\
\hline Polymastia sp. (sponge) & & & & $0.1 \quad(0.1)$ & 0.0 & 40.1 & & & $0.2(0.1)$ & 69.0 \\
\hline $\begin{array}{l}\text { Beneath Evechinus } \\
\text { chloroticus }\end{array}$ & & & & & & & $\begin{array}{lll}0.3 & (0.1) & 0.5\end{array}$ & 100.0 & & \\
\hline Sand & & & & $3.9(0.5)$ & 2.2 & 7.4 & & & & \\
\hline Bare rock/coralline paint & $1.9(0.3)$ & 0.4 & 14.0 & $22.7(6.2)$ & 13.0 & 6.6 & $63.6(11.5) 99.5$ & 14.9 & & \\
\hline Vertical rock faces & $0.5 \quad(0.1)$ & 0.1 & 15.1 & & & & & & & \\
\hline Total & $472.0(76.1)$ & & 49.8 & $174.2(17.7)$ & & 17.1 & $63.9(11.5)$ & 15.4 & $413.6(67.1)$ & 19.1 \\
\hline
\end{tabular}

Carpophyllum forest and turf flats, and 28 to $52 \%$ in the Ecklonia forest (Table 9). The very high upper values estimated for the consumption of total epifaunal and crustacean production on the urchin barrens were strongly influenced by the high productivity resulting from a large recruitment pulse of juvenile tripterygiids (Forsterygion varium) prior to censusing, and can be disregarded since it is almost certain that most of these fish would disappear during the following few weeks (Connell \& Jones 1991). The lower value of $20 \%$ is probably a much more realistic estimate of fish consumption of total epifaunal production. At the level of the entire reef, fish consumed $\sim 26 \%$ of total epifaunal production [taken to be the average of values obtained from Methods (1) and (2) in Table 9, except for the urchin barrens, where the value obtained from 
Method (2) was used, scaled for habitat extents provided by Ayling (1978)\}. Crustaceans $>1 \mathrm{~mm}$ sieve size are the primary prey of small predatory fish (Edgar \& Shaw 1995), and it was estimated that all of their production was consumed in the Ecklonia forest and urchin barrens habitats. However, fish only consumed 8 to $13 \%$ of production of crustaceans $>1 \mathrm{~mm}$ sieve size in the Carpophyllum forest, and 15 to $38 \%$ in the turf flats

\section{Seasonality}

In the turf flats habitat at Goat Island Bay, epifauna were about 4 orders of magnitude more abundant than any other animal group throughout the entire year (Fig. 1a). Epifauna were also the major contributors to faunal biomass in all 4 seasons, always comprising at least an order of magnitude more biomass than any

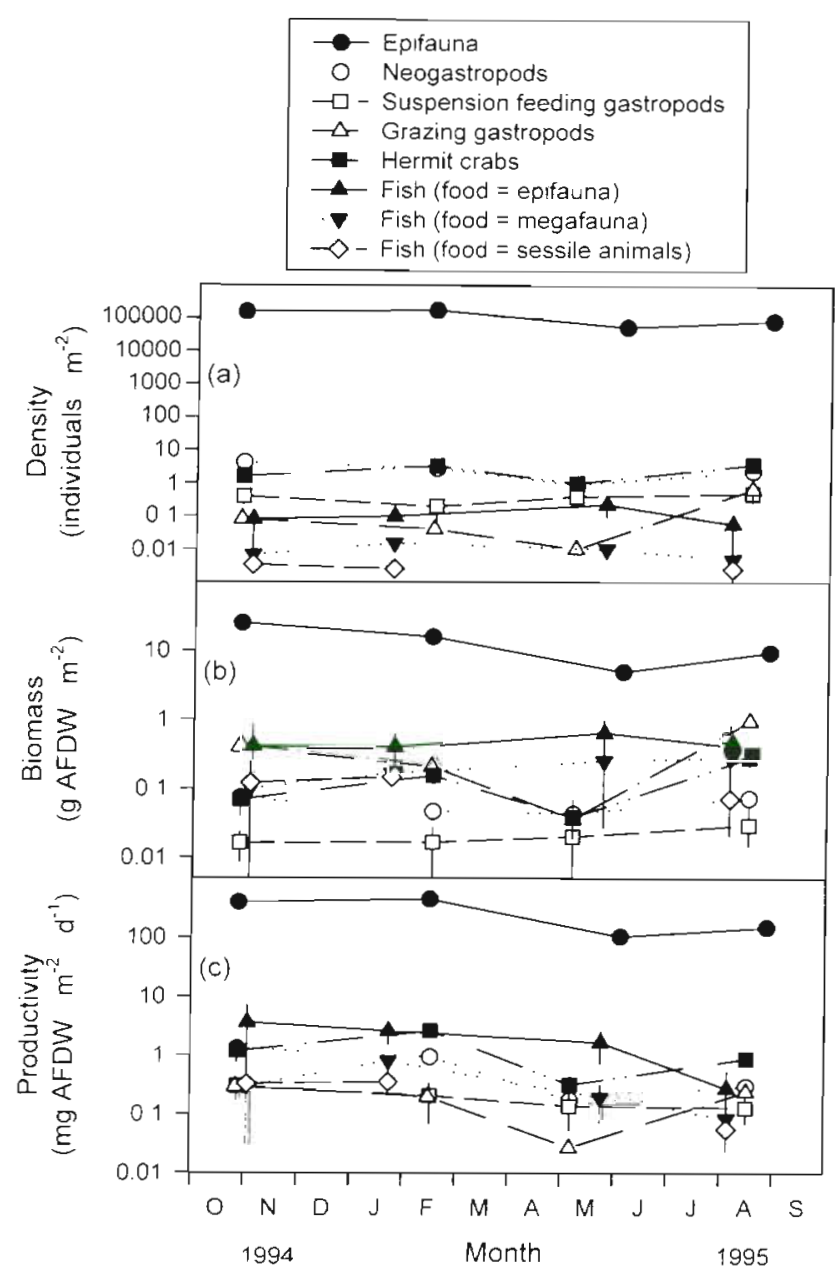

Fig. 1. Animals $>0.5 \mathrm{~mm}$ sieve size inhabiting turf flats habitat vs time. (a) Density, (b) biomass, and (c) productivity. Bars represent $1 \mathrm{SE}$
Table 9. Percentage of production by total epifauna and crustaceans $>1 \mathrm{~mm}$ sieve size consumed by fish within 4 subtidal rocky reef habitats. See 'Methods: Megafauna' for details regarding calculations

\begin{tabular}{|lcccc|}
\hline $\begin{array}{c}\text { Prey class } \\
\text { Method }\end{array}$ & $\begin{array}{c}\text { Carpophyl- } \\
\text { lum forest }\end{array}$ & $\begin{array}{c}\text { Ecklonia } \\
\text { forest }\end{array}$ & $\begin{array}{c}\text { Urchin } \\
\text { barrens }\end{array}$ & $\begin{array}{r}\text { Turf } \\
\text { flats }\end{array}$ \\
\hline $\begin{array}{l}\text { Total epifauna } \\
1\end{array}$ & 6 & 52 & 179 & 7 \\
2 & 4 & 28 & 20 & 3 \\
Crustaceans $>1 \mathrm{~mm}$ & & & \\
1 & 13 & 303 & 1163 & 38 \\
2 & 8 & 167 & 134 & 15 \\
\hline
\end{tabular}

other group, with fish preying upon epifauna usually second (Fig. 1b). The pattern was consistent for productivity, with epifauna always at least 2 orders of magnitude more productive than the next group (again, usually fish preying upon epifauna) (Fig. 1c).

Scaling factors calculated from measurements of annual variability in the turf flats habitat for epifauna were 0.756 (density), 0.548 (biomass) and 0.653 (productivity). The respective values for the megafauna were $0.891,1.155$ and 0.777 . Values were lower than 1 for everything except megafaunal biomass, indicating a trend for values of density, biomass and productivity measured in spring to be higher than the mean annual values. These factors were used to generate average annual estimates of density, biomass and productivity for the other 3 habitats from measurements made during spring.

\section{Reef-wide annual density, biomass and productivity}

When estimated average annual density, biomass and productivity values for each habitat were combined according to the relative habitat prevalences to yield single reef-level values, the epifaunal contribution decreased due to the high coverage of the Ecklonia forest and urchin barrens habitats in which (1) total faunal productivity was relatively low and (2) the epifaunal contribution to this productivity was relatively low (Table 10). Even so, epifauna still contributed $\sim 19 \%$ of faunal biomass, and $\sim 78 \%$ of secondary productivity. The biomass of echinoids was high $(43 \%)$, but their productivity was low (3\%). Grazing gastropods made substantial contributions to biomass $(27 \%)$ and productivity $(11 \%)$, while fish preying upon epifauna were the next most important group $(4 \%$ of biomass, $5 \%$ of productivity). As described above, however, the importance of these fish may have been overestimated due to recruitment of tripterygiids to the urchin barrens prior to censusing. 
Table 10. Estimated average annual density, biomass and productivity of animals $>0.5 \mathrm{~mm}$ sieve size across the entire reef. See 'Methods: Seasonality' and 'Methods: Reef-wide annual density, biomass and productivity' for details regarding calculations

\begin{tabular}{|c|c|c|c|c|c|c|}
\hline \multirow[t]{2}{*}{ Taxon } & \multicolumn{2}{|c|}{ Density (ind. $\mathrm{m}^{-2}$ ) } & \multicolumn{2}{|c|}{ Biomass (g AFDW $\mathrm{m}^{-2}$ ) } & \multicolumn{2}{|c|}{ Productivity (g AFDW $\mathrm{m}^{-2} \mathrm{yr}^{-1}$ ) } \\
\hline & Mean & $\%$ & Mean & $\%$ & Mean & $\%$ \\
\hline \multicolumn{7}{|l|}{ Fish } \\
\hline Feeding on seaweeds & 0.00 & 0.00 & 0.05 & 0.18 & 0.01 & 0.02 \\
\hline Feeding on epifauna & 3.35 & 0.01 & 1.07 & 3.55 & 2.61 & 5.23 \\
\hline Feeding on megafauna & 0.01 & 0.00 & 0.35 & 1.18 & 0.10 & 0.20 \\
\hline Feeding on sessile animals & 0.00 & 0.00 & 0.12 & 0.40 & 0.06 & 0.12 \\
\hline Spiny lobsters & 0.01 & 0.00 & 0.71 & 2.37 & 0.05 & 0.10 \\
\hline Brachyuran crabs & 0.58 & 0.00 & 0.55 & 1.83 & 0.52 & 1.03 \\
\hline Hermit crabs & 1.71 & 0.00 & 0.22 & 0.74 & 0.36 & 0.72 \\
\hline Echinoids & 2.56 & 0.01 & 12.80 & 42.52 & 1.44 & 2.89 \\
\hline \multicolumn{7}{|l|}{ Grazing gastropods } \\
\hline On seafloor & 30.28 & 0.06 & 7.01 & 23.28 & 4.70 & 9.41 \\
\hline On seaweeds & 12.49 & 0.02 & 1.26 & 4.18 & 0.61 & 1.23 \\
\hline Suspension-feeding gastropods & 0.03 & 0.00 & 0.00 & 0.00 & 0.01 & 0.01 \\
\hline Neogastropods & 4.55 & 0.01 & 0.21 & 0.71 & 0.47 & 0.95 \\
\hline Epifauna & 49961 & 99.89 & 5.74 & 19.07 & 39.02 & 78.08 \\
\hline Total & 50017 & & 30.11 & & 49.97 & \\
\hline
\end{tabular}

\section{DISCUSSION}

This study is the first to quantify directly the contribution of small mobile invertebrates to the flux of materials on subtidal rocky reefs. As predicted by Edgar \& Moore (1986), the high densities and rapid turnover rates of epifauna make them very productive relative to other reef-dwelling animals. Their contribution to total annual secondary productivity was $\sim 78 \%$ on the scale of the entire reef, and up to $99 \%$ in finely structured vegetated habitats. Since productivity is proportional to other metabolic rate parameters (all scale to body mass with a power of $\sim 0.75$; Peters 1983 ), this indicates that epifauna are the major consumers and nutrient recyclers amongst the reef-dwelling fauna, and hence deserve inclusion in trophic models such as those of Miller et al. (1971) and Newell et al. (1982)

The high productivity of the epifauna also indicates that more attention needs to be paid to their functional role, i.e. their ability to influence the distribution and abundance of other organisms. The major challenge is to find ways of experimentally manipulating epifaunal abundances under realistic conditions in the field. This has proven to be difficult due to the small size and high mobility of epifaunal individuals (e.g. Edgar \& Aoki 1993). Nevertheless, it is becoming clear that epifauna are capable of significantly reducing abundances of seaweeds (Kennelly 1983, Tegner \& Dayton 1987), epiphytic algae (Brawley \& Fei 1987, Duffy 1990), and newly settled sessile animals (Osman et al. 1992), and as prey items the epifauna appear to regulate populations of many reef fish species (Holbrook \& Schmitt 1996, Holbrook et al. 1997).

\section{Factors affecting epifaunal productivity}

Epifaunal productivity was highest in habitats occupied by brown seaweeds and articulated corallines, and lowest in the crustose coralline-dominated urchin barrens, probably because the former provide better shelter from fish predation (Coull \& Wells 1983), a larger surface from which to graze (Edgar 1991a), and a better anchorage for resisting removal by wave action (Hacker \& Steneck 1990). It follows that factors influencing the relative abundances and dynamics of these habitat patches are likely to have a major impact on reef-level epifaunal productivity. Here echinoids are of great functional importance, because in spite of their low contribution to the flux of organic matter they can strongly influence abundance patterns of erect seaweeds (Lawrence 1975, Harrold \& Pearse 1987). This has been demonstrated on a large scale in many parts of the northeastern Pacific, where the suppression of urchin populations by reintroduced sea otters causes a predictable shift from unproductive barren grounds to dense kelp forests that support highly productive epifaunal assemblages (Estes et al. 1978, Simenstad et al. 1978). Physical agents, such as storms, and El Nino conditions that interrupt the supply of 
nutrients, can also remove large seaweeds and turfing algae (Dayton 1994), having important long-term effects on epifaunal productivity that are reflected in the abundances of predatory fish (Holbrook \& Schmitt 1996, Holbrook et al. 1997).

Where the above factors allow suitable habitat to exist, epifaunal productivity is often affected by variation in light intensity along gradients of depth and turbidity, via its impact on epiphytic algal food sources (Edgar 1991b, 1993). Water movement is also important, as shores exposed to strong wave action or currents can support high densities of suspension-feeding amphipods (Fenwick 1976, Edgar 1983). The effects of fish predation on epifaunal productivity have been difficult to evaluate due to epifaunal movement in and out of fish exclusion cages (Edgar \& Aoki 1993). Results of studies to date have been inconsistent (Edgar \& Aoki 1993), although it appears that when food is limiting to the epifauna the main effect of predatory fish is to alter the size structure of epifaunal assemblages by the selective consumption of larger individuals (Edgar 1993, Edgar \& Aoki 1993). While not influencing total epifaunal productivity, this predation will lower the proportion of epifaunal productivity that is composed of individuals large enough to be consumed by fish (Edgar \& Shaw 1995)

\section{Fate of epifaunal production}

Small fishes are almost certainly the major predators of epifauna on temperate reefs. In finely structured vegetated habitats, small predatory fish were the next most productive group after the epifauna, confirming the widely perceived importance of the epifauna-fish trophic link (e.g Edgar \& Moore 1986). A high proportion of reef fishes feed on epifauna for at least the early parts of their lives (Jones 1988, Holbrook et al. 1990), and these fishes in turn support a range of larger predators (Estes et al. 1978, Simenstad et al. 1978, Russell 1983).

However, it was estimated that only $\sim 26 \%$ of epifaunal production was consumed by fish, a value in agreement with the results of several soft-sediment studies (Edgar \& Shaw 1995 and references therein). Decapods such as caridean shrimps and crabs are probably the only other potentially important predators (Howard 1984), but were rare on seaweeds in this study (pers. obs.). The intensity of fish predation was probably underestimated in the turf flats due to the undersampling of transient schools of juvenile mackerels and carangids that sometimes fed on epifauna there, but non-resident fish were not seen feeding in any of the other habitats (pers. obs.).

Epifauna contributed $\sim 78 \%$ of secondary productivity on the reef, and $\sim 74 \%$ of this production did not appear to be consumed, meaning that at least $\sim 58 \%$ of total secondary productivity on the reef is apparently not utilized by higher trophic levels. What is the fate of this component? It is possible that a substantial proportion is advected from the reef when epifaunal individuals enter the water column at night as demersal zooplankton (Hobson \& Chess 1976). The fate of animals transported from the reef is completely unknown in terms of their survival and likelihood of relocating suitable habitat and their importance to organisms in other

Table 11. Estimated annual productivity of animals $>0.5 \mathrm{~mm}$ sieve size in shallow coastal habitats. Where necessary, conversion factors cited in Riddle et al. (1990) were used to derive AFDW from other measures of biomass. Habitats are ranked in decreasing order of productivity

\begin{tabular}{|llccc}
\hline Habitat & Locality & Depth & $\begin{array}{c}\text { Productivity } \\
\text { (g AFDW } \text { - }^{-2} \mathrm{Yr}^{-1} \text { ) }\end{array}$ & Source \\
\hline Macrophyte detritus & California & Subtidal & -7000 & Vetter (1995) \\
Mussel bed & Wadden Sea & Intertidal & 468 & Asmus (1987) \\
Carpophyllum forest & New Zealand & Subtidal & 115 & Present study \\
Turf flats & New Zealand & Subtidal & 100 & Present study \\
Mud flat & California & Intertidal & $53-100$ & Nichols (1977) \\
Mud flat & Portugal & Intertidal & 72 & Sprung (1994) \\
Seagrass bed & Portugal & Intertidal & 58 & Sprung (1994) \\
Ecklonia forest & New Zealand & Subtidal & 51 & Present study \\
Sand flat & Portugal & Intertidal & 34 & Sprung (1994) \\
Urchin barrens & New Zealand & Subtidal & 30 & Present study \\
Fine sand & Wales & Subtidal & 26 & Warwick et al. (1978) \\
Sediments & Delaware & Subtidal & $4-47$ & Riddle et al. (1990) \\
Coral reef lagoon sand & Great Barrier Reef & Subtidal & 19 & Warwick \& Price (1975) \\
Mud flat & England & Intertidal & 13 & Buchanan \& Warwick (1974) \\
Mud & England & Subtidal & 2 & \\
\hline
\end{tabular}


habitats. Observations and experiments on the epifauna of Carpophyllum plumosum var. capillifolium have indicated that most epifaunal individuals and taxa did not move into the water column at night (Taylor 1998), but in other studies in northeastern New Zealand (Moltschaniwskyj 1989, White 1989) and elsewhere (Jansson \& Källander 1968, Fincham 1974, Hobson $\&$ Chess 1976 ) the presence of numerous epifaunal individuals in the water column at night has been observed or inferred.

\section{What sources of primary production fuel the epifauna?}

Epifaunal assemblages typically comprise a diverse array of taxa that can collectively consume a wide variety of living and detrital plant material (Edgar \& Moore 1986, Brawley 1992), and this ability to utilise a broad range of resources may contribute to their high productivity (e.g. Chapin et al. 1997). Since kelp forests are extremely productive and release most of their production as detritus (Mann 1973), it is tempting to follow researchers working in the eastern Pacific and conclude that kelp detritus is the major food source for reef-dwelling epifauna (Simenstad et al. 1977, 1978, Moreno \& Jara 1984, Ebeling et al. 1985). However, this is not necessarily so, as evidence exists that epiphytic algae are the primary food source for epifauna in many habitats, including kelp forests (Edgar 1991a, 1993). A discussion of this issue is beyond the scope of this paper, but identifying the sources of primary production that drive epifaunal productivity is clearly important for a better understanding of rocky reef ecosystems.

\section{Other flux studies}

To enable comparison of results from the present study with figures from other coastal benthic habitats, I compiled annual productivity values from published studies that used a sieve mesh size of $0.5 \mathrm{~mm}$ to sample the benthos (Table 11). Productivity in the finely structured vegetated habitats (Carpophyllum forest and turf flats) was high, being surpassed only by an extremely productive leptostracan-dominated crustacean assemblage inhabiting localised mats of macrophyte detritus in submarine canyons off southern California (Vetter 1995) and an intertidal mussel bed in the Wadden Sea (Asmus 1987). Productivities of all habitats examined in this study were higher than values for most subtidal habitats elsewhere, which were all soft-sediment with the exception of those described by Asmus (1987) and Vetter (1995).
Acknowledgements. I am grateful to B. Jackson, S. Kelly and M. Taylor for help in the field, and to the New Zealand Department of Conservation for allowing me to sample within the Cape Rodney to Okakari Point Marine Reserve. I thank R. Babcock, R. Cole, M. Hay, M. Miller and the referees for their comments on drafts of the manuscript. This research was supported by a New Zealand Universities' Postgraduate Scholarship.

\section{LITERATURE CITED}

Andrew NL, Choat $\mathrm{JH}$ (1982) The influence of predation and conspecific adults on the abundance of juvenile Evechinus chloroticus (Echinoidea: Echinometridae). Oecologia 54: $80-87$

Asmus H (1987) Secondary production of an intertidal mussel bed community related to its storage and turnover compartments. Mar Ecol Prog Ser 39:251-266

Ayling AM (1978) Cape Rodney to Okakari Point Marine Reserve survey. Auckland University Bindery, Auckland

Ayling AM (1981) The role of biological disturbance in temperate subtidal encrusting communities. Ecology 62: $830-847$

Ayling T, Cox GJ (1982) Collins guide to the sea fishes of New Zealand. Collins, Auckland

Branch GM, Griffiths CL (1988) The Benguela ecosystem. Part $V$ The coastal zone. Oceanogr Mar Biol Annu Rev 26: $395-486$

Brawley SH (1992) Mesoherbivores. In: John DM, Hawkins $\mathrm{SJ}$, Price $\mathrm{JH}$ (eds) Plant-animal interactions in the marine benthos. Clarendon Press, Oxford, p 235-263

Brawley SH, Fei XG (1987) Studies of mesoherbivory in aquaria and in an unbarricaded mariculture farm on the Chinese coast. J Phycol 23:614-623

Brey $\mathrm{T}$ (1990) Estimating productivity of macrobenthic invertebrates from biomass and mean individual weight. Meeresforschung 32:329-343

Buchanan JB, Warwick RM (1974) An estimate of benthic macrofaunal production in the offshore mud of the Northumberland coast. J Mar Biol Assoc UK 54:197-222

Chapin FS III, Walker BH, Hobbs RJ, Hooper DU, Lawton JH, Sala OE, Tilman D (1997) Biotic control over the functioning of ecosystems. Science 277:500-504

Choat JH, Kingett PD (1982) The influence of fish predation on the abundance cycles of an algal turf invertebrate fauna. Oecologia 54:88-95

Choat JH, Schiel DR (1982) Patterns of distribution and abundance of large brown algae and invertebrate herbivores in subtidal regions of northern New Zealand. J Exp Mar Biol Ecol 60:129-162

Cole RG, Babcock RC (1996) Mass mortality of a dominant kelp (Laminariales) at Goat Island, north-eastern New Zealand. Mar Freshwat Res 47:907-911

Connell SD. Jones GP (1991) The influence of habitat complexity on postrecruitment processes in a temperate reef fish population. J Exp Mar Biol Ecol 151:271-294

Coull BC, Wells JBJ (1983) Refuges from fish predation: experiments with phytal meiofauna from the New Zealand rocky intertidal. Ecology 64:1599-1609

Creese RG (1988) Ecology of molluscan grazers and their interactions with marine algae in north-eastern New Zealand: a review. NZ J Mar Freshwat Res 22:427-444

Crisp DJ (1984) Energy flow measurements. In: Holme NA, McIntyre AD (eds) Methods for the study of marine benthos, 2nd edn. Blackwell Scientific Publications, Oxford, p 284-372 
Dayton PK (1994) Community landscape: scale and stability in hard bottom marine communities. In: Giller PS, Hildrew AG, Raftaelli DG (eds) Aquatic ecology: scale, pattern and process. Blackwell Scientific Publications, Oxford, p 289-332

Duffy JE (1990) Amphipods on seaweeds: partners or pests? Oecologia 83:267-276

Ebeling AW, Laur DR, Rowley RJ (1985) Severe storm disturbances and reversal of community structure in a southern California kelp forest. Mar Bıol 84:287-294.

Edyar GJ (1983) The ecology of south-east Tasmanian phytal animal communities. I. Spatial organization on a local scale. J Exp Mar Biol Ecol 70:129-157

Edgar GJ (1990) The use of the size structure of benthic macrofaunal communities to estimate faunal biomass and secondary production. J Exp Mar Biol Ecol 137:195-214

Edgar GJ (1991a) Artificial algae as habitats for mobile epifauna: factors affecting colonization in a Japanese Sargassum bed. Hydrobiologia 226:111-118

Edgar GJ (1991b) Distribution patterns of mobile epifauna associated with rope fibre habitats within the Bathurst Harbour estuary, south-western Tasmania. Estuar Coast Shelf Sci 33:589-604

Edgar GJ (1993) Measurement of the carrying capacity of benthic habitats using a metabolic-rate based index. Oecologia 95:115-121

Edgar GJ, Aoki M (1993) Resource limitation and fish predation: their Importance to mobile epifauna associated with Japanese Sargassum. Oecologia 95:122-133

Edgar GJ, Moore PG (1986) Macro-algae as habitats for motile macrofauna. Monogr Biol 4:255-277

Edgar GJ, Shaw C (1995) The production and trophic ecology of shallow-water fish assemblages in southern Australia. II. Diets of fishes and trophic relationships between fishes and benthos at Western Port, Victoria. J Exp Mar Biol Ecol 194:83-106

Estes JA, Smith NS, Palmisano JF (1978) Sea otter predation and community organization in the western Aleutian Islands, Alaska. Ecology 59:822-833

Evans JH (1992) Leigh climate report 1991. Leigh Laboratory Bulletin 27:1-56

Fenwick GD (1976) The effect of wave exposure on the amphipod fauna of the alga Caulerpa brownil. J Exp Mar Biol Ecol 25:1-18

Field JG, Jarman NG, Dieckmann GS, Griffiths CL, Velimirov B, Zoutendyk P (1977) Sun, waves, seaweed and lobsters: the dynamics of a west coast kelp-bed. S Afr J Sci 73:7-10

Fincham AA (1974) Periodir swimming behaviour of amphipods in Wellington Harbour. NZ J Mar Freshwat Res 8:505-521

Francis MP (1994) Growth of Juvenile snapper, Pagrus auratus. NZ J Mar Freshwat Res 28:201-218

Gordon DP, Ballantine WJ (1976) Cape Rodney to Okakari Point Marine Reserve: review of knowledge and bibliography to December 1976. Tane Suppl 22:1-146

Hacker SD, Steneck RS (1990) Habitat architecture and the abundance and body-size-dependent habitat selection of a phytal amphipod. Ecology 71:2269-2285

Harrold C, Pearse JS (1987) The ecological role of echinoderms in kelp forests. Echinoderm Stud 2:137-233

Hartley G (1978) The population biology of four co-occurring herbivorous subtidal gastropods. MSc thesis, University of Auckland

Hobson ES, Chess JR (1976) Trophic interactions among fishes and zooplankters near shore at Santa Catalina Island, California. Fish Bull 74:567-598

Holbrook SJ, Schmitt RJ (1989) Resource overlap, prey dynamics, and the strength of competition. Ecology 70 : $1943-1953$

Holbrook SJ, Schmitt RJ (1996) On the structure and dynamics of temperate reef fish assemblages: are resources tracked? In: Cody ML, Smallwood. J (eds) Long-term studies of vertebrate communities. Academic Press, San Diego, p $19-48$

Holbrook SJ, Schmitt RJ, Ambrose RF (1990) Biogenic habitat structure and characteristics of temperate reef fish assemblages. Aust J Ecol 15:489-503

Holbrook SJ, Schmitt RJ, Stephens JS Jr (1997) Changes in an assemblage of temperate reef fishes associated with a climate shift. Ecol Appl 7:1299-1310

Howard RK (1984) The trophic ecology of caridean shrimps in an eelgrass community. Aquat Bot 18:155-174

Jansson BO, Källander C (1968) On the diurnal activity of some littoral peracarid crustaceans in the Baltic Sea. J Exp Mar Biol Ecol 2:24-36

Jones GP (1988) Ecology of rocky reef fish of north-eastern New Zealand: a review. NZ J Mar Freshwat Res 22: $445-462$

Kennelly SJ (1983) An experimental approach to the study of factors affecting algal colonization in a sublittoral kelp forest. J Exp Mar Biol Ecol 68:257-276

Lawrence JM (1975) On the relationships between marine plants and sea urchins. Oceanogr Mar Biol Annu Rev 13: 213-286

Longhurst AR, Pauly D (1987) Ecology of tropical oceans Academic Press, San Diego

Mann KH (1973) Seaweeds: their productivity and strategy for growth. Science 182:975-981

Maurer D, Howe S, Leathem W (1992) Secondary production of macrobenthic invertebrates from Delaware Bay and coastal waters. Int Rev Gesamten Hydrobiol 77:187-201

Miller RJ, Mann KH, Scarratt DJ (1971) Production potential of a seaweed-lobster community in eastern Canada. J Fish Res Board Can 28:1733-1738

Moltschaniwskyj NA (1989) The settlement and recruitment of Upeneichthys lineatus (Pisces: Mullidae). MSc thesis, University of Auckland

Moreno CA, Jara HF (1984) Ecological studies on fish fauna associated with Macrocystis pyrifera belts in the south of Fueguian Islands, Chile. Mar Ecol Prog Ser 15:99-107

Newell RC, Field JG, Griffiths CL (1982) Energy balance and significance of microorganisms in a kelp bed community. Mar Ecol Prog Ser 8:103-113

Nichols FH (1977) Infaunal biomass and production on a mudflat, San Francisco Bay, California. In: Coull BC (ed) Ecology of marine benthos. University of South Carolina Press, Columbia, p 339-357

Osman RW, Whitlatch RB, Malatesta RJ (1992) Potential role of micro-predators in determining recruitment into a marine community Mar Ecol Prog Ser 83:35-43

Pauly D, Christensen V (1995) Primary production required to sustain global fisheries. Nature 374:255-257

Pauly D, David N (1981) ELEFAN I, a BASIC program for the objective extraction of growth parameters from length-frequency data. Meeresforschung 28:205-211

Peters RH (1983) The ecological implications of body size. Cambridge University Press, Cambridge

Riddle MJ, Alongi DM, Dayton PK, Hansen JA, Klumpp DW (1990) Detrital pathways in a coral reef lagoon. I. Macrofaunal biomass and estimates of production. Mar Biol 104 $109-118$

Russell BC (1983) The food and feeding habits of rocky reef fish of north-eastern New Zealand. NZ J Mar Freshwat Res 17:121-145 
Saila SB, Annala JH, McKoy JL, Booth JD (1979) Application of yield models to the New Zealand rock lobster fishery. NZ J Mar Freshwat Res 13:1-11

Schiel DR (1988) Algal interactions on shallow subtidal reefs in northern New Zealand: a review. NZ J Mar Freshwat Res 22:481-489

Simenstad CA, Estes JA, Kenyon KW (1978) Aleuts, sea otters, and alternate stable-state communities. Science 200:403-411

Simenstad CA, Isakson JS, Nakatani RE (1977) Marine fish communities. In: Merritt ML, Fuller RG (eds) The environment of Amchitka Island. Energy Research and Development Administration, Oak Ridge, p 451-492

Snowdon P (1991) A ratio estimator for bias correction in logarithmic regressions. Can J For Res 21:720-724

Sprung M (1994) Macrobenthic secondary production in the intertidal zone of the Ria Formosa - a lagoon in southern Portugal. Estuar Coast Shelf Sci 38:539-558

Taylor RB (1997) The role of small mobile epifauna in subtidal rocky reef ecosystems. $\mathrm{PhD}$ thesis, University of Auckland

Taylor RB (1998) Short-term dynamics of a seaweed epifaunal assemblage. J Exp Mar Biol Ecol 227:67-82

Taylor RB, Blackburn RI, Evans JH (1995) A portable batterypowered suction device for the quantitative sampling of small benthic invertebrates. J Exp Mar Biol Ecol 194:1-7

Taylor RB, Cole RG (1994) Mobile epifauna on subtidal brown seaweeds in northeastern New Zealand. Mar Ecol Prog Ser 115:271-282

Editorial responsibility: Otto Kinne (Editor)

Oldendorf/Luhe, Germany
Taylor RB, Willis TJ (1998) Relationships amongst length weight and growth of northeastern New Zealand reef fishes. Mar Freshwat Res 49:255-260

Tegner MJ, Dayton PK (1987) El Niño effects on southern California kelp forest communities. Adv Ecol Res 17:243-279

Topping J (1962) Errors of observation and their treatment, 3rd edn. Chapman and Hail, London

Velimirov B, Field JG, Griffiths CL, Zoutendyk P (1977) The ecology of kelp bed communities in the Benguela upwelling system: analysis of biomass and spatial distribution. Helgol Wiss Meeresunters 30:495-518

Vetter EW (1995) Detritus-based patches of high secondary production in the nearshore benthos. Mar Ecol Prog Ser 120:251-262

Walker MM (1981) Influence of season on growth of the sea urchin Evechinus chloroticus. NZ J Mar Freshwat Res 15: 201-205

Warwick RM, George CL, Davies JR (1978) Annual macrofauna production in a Venus community. Estuar Coast Mar Sci 7:215-241

Warwick RM, Price R (1975) Macrofauna production in an estuarine mud-flat. J Mar Biol Assoc UK 55:1-18

West SA (1991) Population biology and ecology of three species of Maurea (Trochidae: Gastropoda). MSc thesis, University of Auckland

White SE (1989) Ecology and behaviour of mobile epifauna on rocky reef macroalgae. MSc thesis, University of Auckland

Submitted: January 5, 1998; Accepted: July 7, 1998

Proofs received from author(s): September 21, 1998 